\title{
Residual Doses of Herbicide Affect the Initial Development of Hymenaea stigonocarpa
}

Kamilla Alves Barbosa ${ }^{1}$ (1) 0000-0003-1289-4059

Walquíria Fernanda Teixeira ${ }^{2}$ (1) 0000-0002-0641-0815

Luís Henrique Soares ${ }^{1}$ (D) 0000-0002-0737-3745

Evandro Binotto Fagan ${ }^{1}$ (1) 0000-0002-0281-5874

\begin{abstract}
The aim of this study was to assess the effect of subdoses of 2,4-D + picloram on the emergence and initial growth of Hymenaea stigonocarpa. Three experiments were carried out. In the first one, the seeds were planted in sand with residues of 2,4-D + picloram $\left(0 ; 0.02 ; 0.10 ; 0.20\right.$ and $\left.0.40 \mathrm{~L} \mathrm{ha}^{-1}\right)$. The second experiment was conducted with seedlings, using the same treatment of experiment I. In experiment III, the seeds were planted in Red Latosol contaminated with subdoses of $2,4-\mathrm{D}+$ picloram $\left(0 ; 0.02 ; 0.08 ; 0.24 ; 0.48\right.$ and $\left.0.96 \mathrm{~L} \mathrm{ha}^{-1}\right)$. The contamination of the sand substrate with subdoses of 2,4-D + picloram inhibits the emergence and senescence of Hymenaea stigonocarpa plants. Moreover, when seeds of this species were cultivated in Red Latosol with residual doses between 0.04 and $0.96 \mathrm{~L} \mathrm{ha}^{-1}$, emergence and emergence speed index declined.
\end{abstract}

Keywords: jatobá-do-cerrado, herbicide residue, tolerance.

\section{INTRODUCTION AND OBJECTIVES}

Some cultivated species are susceptible to the interference of weeds during growth, requiring chemical control, especially in large-scale production (Peres-Oliveira et al., 2016; Silva et al., 2009). As such, the use of herbicides has become increasingly common in Brazilian agriculture.

A type of herbicide is the 2,4-D + picloram, an auxin or auxin-mimicking formulation that acts on the growth of sensitive plants, triggering metabolic and biochemical changes. This herbicide is widely used in pastures and rice (Oryza sativa L.), wheat (Triticum aestivum L.) and sugarcane (Saccharum officinarum L.) crops. Picloram has a long residual period and can be found in soil up to three years after application (D’Antonino et al., 2009; Mancuso et al., 2011).

Herbicide residues in soil are considered responsible for reduced yield in successor crops (Alvarenga et al., 2003). The effects of plant intoxication caused by herbicide residues range between lower yields and the formation of morphophysiological anomalies. In a study conducted by Barros et al. (2014), residual doses of 2,4-D + picloram caused significant damage to eucalyptus species.

The disordered exploitation of natural resources means that degraded areas must be recovered with native species such as Protium heptaphyllum, Myrcia splendens, Qualea multiflora, Tapirira guianensis, Magonia pubescens, Copaifera langsdorffi Desf (Bendito et al., 2018), and Hymenaea stigonocarpa, the last been prioritized for this purpose (Durigan, 2003).

However, no studies have shown the effect of this herbicide on native Cerrado species. Contaminated areas are difficult to recover, considering that these herbicides may compromise plant development. Thus, this study aimed to assess the behavior of Hymenaea stigonocarpa cultivated in soil contaminated with residues of 2,4-D + picloram.

\section{MATERIALS AND METHODS}

The experiments were carried out at the Center for Research in Physiology and Stress of Plants (NUFEPNúcleo de Pesquisa em Fisiologia e Estresse de Plantas) of

\footnotetext{
${ }^{1}$ Centro Universitário de Patos de Minas (Unipam), Patos de Minas, MG, Brasil

${ }^{2}$ Universidade de São Paulo (USP), Piracicaba, SP, Brasil
} 
the Centro Universitário de Patos de Minas (Unipam), in the municipality of Patos de Minas, Minas Gerais (MG). The seeds and seedlings of Hymenaea stigonocarpa Mart. ex Hayne were donated by the State Institute of Forests (IEF-Instituto Estadual de Florestas).

Three experiments were conducted to assess the residual effect of the herbicide on the germination and initial development of Hymenaea stigonocarpa.

All experiments were performed in a plant growth chamber using a completely randomized design. The growth chamber has a system of fluorescent lights activated by a timer, simulating a 12-hour photoperiod and incident solar radiation of approximately $1,000 \mathrm{~W} \mathrm{~m}^{-2}$. The area was maintained at a temperature of $25^{\circ} \mathrm{C}$ during the day and $18{ }^{\circ} \mathrm{C}$ during the night, with air humidity set at $70 \%$, controlled by an air conditioner and dehumidifier.

Experiments I and II (conducted in pots filled with sand) were composed of five treatments and six repetitions (Table 1) and experiment III (in pots containing Eutroferric Red Latosol with high clay texture $-42 \%$ clay, $20 \%$ silt and $38 \%$ sand, Embrapa, 2006) was composed of six treatments and six repetitions. The treatments consisted of subdoses of the herbicide Tordon ${ }^{\circ}$, whose formulation contains 2,4-D + picloram (240 g L ${ }^{-1}+64 \mathrm{~g} \mathrm{~L}^{-1}$ respectively). The residual doses were estimated based on the belowrecommended concentrations of the herbicide $\left(4.0 \mathrm{~L} \mathrm{ha}^{-1}\right)$, according to the methodology proposed by Nascimento \& Yamashita (2009). The experiment conducted in soil (experiment III) was performed with higher subdoses of herbicide, due to interactions that may occur between the herbicide and charges present in the soil, absorbing part of the product.

Solutions corresponding to each herbicide dose were prepared by diluting the commercial product in distilled water (herbicide solution) to contaminate the soil. At the time of contamination, the substrate was moistened to approximately $80 \%$ of field capacity (Nascimento \& Yamashita, 2009). The substrate was contaminated before planting or seedling transplantation. It is important to highlight that experiments I and II were conducted using washed sand exclusively to isolate the treatment effect on the plants or seeds. However, since sand increases the effect of treatments due to its physical characteristics, residual doses were lower in these experiments. Based on these results, the experiment was conducted in Red Latosol, which best simulates real conditions.

The pots were watered according to their need, which was determined using the gravimetric analysis. A total of $10 \mathrm{~mL}$ of the nutrient solution proposed by Johnson et al. (1957) were applied weekly to each pot.
Table 1. Doses of herbicide 2,4-D + picloram applied on the substrate.

\begin{tabular}{|c|c|c|c|}
\hline \multicolumn{2}{|c|}{ Experiments I e II } & \multicolumn{2}{|c|}{ Experiment III } \\
\hline $\begin{array}{l}\text { Herbicide } \\
\left(\mathrm{L} \mathrm{ha}^{-1}\right)\end{array}$ & $\mathbf{R D}^{\star}(\%)$ & $\begin{array}{l}\text { Herbicide } \\
\left(\mathrm{L} \mathrm{ha}^{-1}\right)\end{array}$ & $\begin{array}{l}\text { RD }^{*} \\
(\%)\end{array}$ \\
\hline 0 & 0 & 0 & 0 \\
\hline 0.02 & 0.5 & 0.04 & 1 \\
\hline 0.10 & 2.5 & 0.08 & 2 \\
\hline 0.20 & 5 & 0.24 & 6 \\
\hline 0.40 & 10 & 0.48 & 12 \\
\hline- & - & 0.96 & 25 \\
\hline
\end{tabular}

* RD: Percentage of herbicide applied, in relation to the recommended dose.

In experiment I, 30 pots with $8 \mathrm{~L}$ of washed sand were used. Before planting, the seeds were scarified with an electric emery to break mechanical dormancy. Later, the seeds were disinfected with a $5 \%$ sodium hypochlorite solution for five minutes. Ten seeds per pot were planted equidistantly at a depth of $3 \mathrm{~cm}$. In this experiment, emergence and emergence speed index (ESI) were assessed.

Emergence was assessed for 35 days. At the end of the observation, ESI was obtained by adding the number of emerged seeds per day, divided by the number of days after planting (DAP), according to Equation 1, as proposed by Maguire (1962):

$$
\mathrm{ESI}=\frac{E_{1}}{t_{1}}+\frac{E_{2}}{t_{2}}+\frac{E_{3}}{t_{3}} \cdots \frac{E_{n}}{t_{n}}
$$

where: $E S I$ is the emergence speed index; $E$ the number of emerged seeds per day; and $t$ the number of days after planting.

Hymenaea stigonocarpa seedlings were used in experiment II. The seedlings (approximately 120 days old) were produced in plastic bags, and they exhibited an average height of $40 \mathrm{~cm}$ and five fully expanded leaves. Planting occurred in the original seedling substrate, that is, with clumps of Red Latosol, in pots filled with $8 \mathrm{~L}$ of washed sand, previously contaminated with herbicide residues. Each pot was repeated in each treatment.

In this experiment the nitrate reductase enzyme activity, the SPAD index, leaf senescence, and dry weight were assessed. Nitrate reductase (NR) enzyme activity occurred seven days after the start of the experiment-removing samples from three leaves in the upper third of the plant completely exposed to light-in four plants per treatment. NR was determined following the methodology proposed by Mulder et al. (1959).

To determine the leaf SPAD index, a portable chlorophyll meter was used (Minolta Spad-502) for instant readings of 
relative chlorophyll content without destroying the leaf. Readings were conducted seven days after seedling transplantation.

Leaf senescence was assessed considering senescent leaves as those with more than $50 \%$ of dead leaf tissue, with the percentage of dead plants also assessed. The aforementioned analyses were carried out at 7 and 14 days after seedling transplantation.

To determine dry weight at $45 \mathrm{DAP}$, each plant organ was packed separately in paper bags, and dried in a forced air oven at a temperature of $65^{\circ} \mathrm{C}$, until constant mass.

Experiment III was performed in $8 \mathrm{~L}$ plastic pots filled with Red Latosol, the soil was obtained from an area not contaminated by herbicides. Ten scarified Hymenaea stigonocarpa seeds per pot were used, with $3 \mathrm{~cm}$ separating each seed, at a depth of $3 \mathrm{~cm}$. Before planting, seeds were disinfected in $5 \%$ sodium hypochlorite solution for $5 \mathrm{~min}$. Emergence and ESI were assessed, as described in experiment I.

Statistical analyses were conducted using Sisvar software (Ferreira, 2010). The data obtained were submitted to analysis of variance and, when significant, the regression models were set at $5 \%$ significance. Dry weight analyses were compared using the Student's t-test, at 5\% significance.

\section{RESULTS AND DISCUSSION}

Applying subdoses of 2,4-D + picloram in sand (experiment I) inhibited the germination of Hymenaea stigonocarpa seeds at all concentrations tested. Germination values of $90 \%$ were observed in the control, while the other germination treatments exhibited values of $0 \%$. For this reason, we did not present this data in tables or figures.

When auxin herbicides-such as 2,4-D + picloramare applied to sensitive plants they cause metabolic and biochemical changes, inducing cell proliferation in tissues, which significantly affects cell wall plasticity. After the use of this herbicides, a considerable increase in cellulose enzymes such as carboxymethylcellulase in roots can be noted (Tomaz, 2011). Thus, the root system of species sensitive to auxin herbicides is rapidly destroyed, inhibiting emergence, as observed here.

In experiment II, conducted with young Hymenaea stigonocarpa plants, residual doses of the herbicide had a negative effect on plant development. The activity of the Nitrate reductase (NR) enzyme declined in plants submitted to residual doses of the herbicide, as follows: $16,29,25$ and $29 \%$ in treatments with $0.02 ; 0.10 ; 0.20$ and $0.40 \mathrm{~L} \mathrm{ha}^{-1}$ of $2,4 \mathrm{D}+$ picloram, respectively (Figure 1a), in relation to the control. This effect was also observed for the SPAD index, presenting a reduction of $23,25,26$ and $25 \%$ compared with the control, for treatments with $0.02 ; 0.10 ; 0.20$ and $0.40 \mathrm{~L} \mathrm{ha}^{-1}$, respectively (Figure 1B).

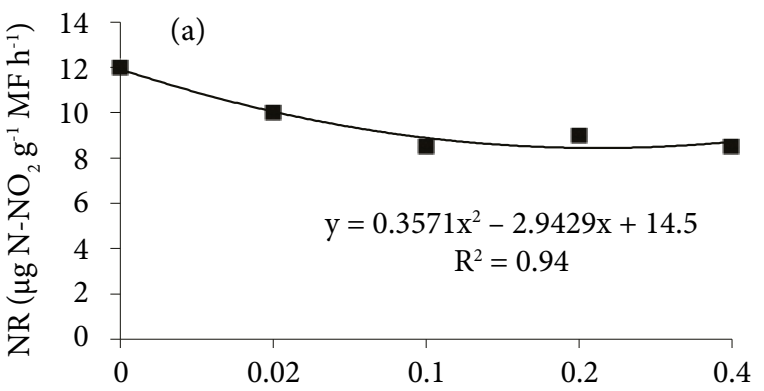

Residual doses of herbicide in sand $\left(\mathrm{L} \mathrm{ha}^{-1}\right)$

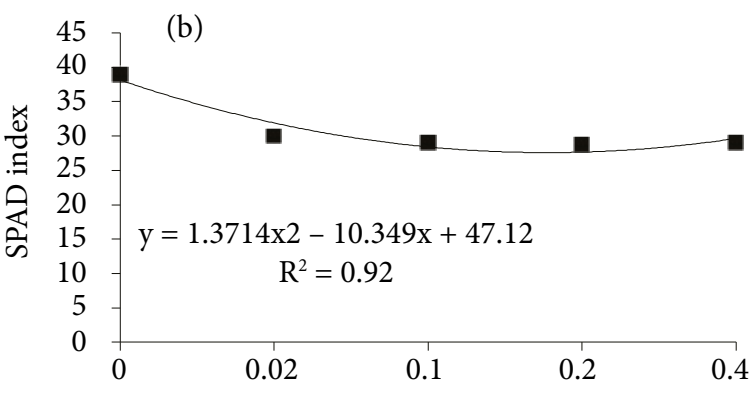

Residual doses of herbicide in sand $\left(\mathrm{L} \mathrm{ha}^{-1}\right)$

Figure 1. Nitrate reductase activity, NR (a) and SPAD index (b) in seedlings of Hymenaea stigonocarpa submitted to residual doses of the herbicide 2,4-D + picloram applied in sand substrate.

The effects caused by herbicide 2,4-D + picloram were documented by Hansen and Grossmann (2000). According to these authors, this compound damages the chloroplast, resulting in leaf chlorosis as well as a decline in chlorophyll, inducing cellular senescence and necrosis. This fact explains the reduced NR enzyme activity and SPAD index in this experiment (Figure 1b).

Nitrate reductase enzyme activity depends on the photosynthetic energy produced (Marschner, 2012). As such, the decline in photosynthetic tissue observed in the SPAD index may have led to decreased energy production, which affected nitrate reductase enzymes (Figure 1a).

Experiments conducted by Barros et al. (2014) in Eucalyptus globulus showed that applying doses between 3 and $6 \mathrm{~L} \mathrm{ha}^{-1}$ decreased photosynthetic activity in plants. In Hymenaea stigonocarpa, subdoses of $0.02 \mathrm{~L} \mathrm{ha}^{-1}$ were sufficient to damage the plants.

Seven days after treatments (DAT), the plants exhibited 55, 70,72 and $87 \%$ leaf senescence for treatments with $0.02 ; 0.10$; 0.20 and $0.40 L h a^{-1}$ of 2,4-D + picloram. At 14 DAT, plants treated with $0.02 \mathrm{~L} \mathrm{ha}^{-1}$ displayed $94 \%$ leaf senescence, while higher doses caused $100 \%$ senescence (Figure 2a). The percent of plant senescence at $7 \mathrm{DAT}$ reached $50 \%$ for those treated with 0.2 and $0.4 \mathrm{~L} \mathrm{ha}^{-1}$ of $2,4 \mathrm{D}+$ picloram. At $14 \mathrm{DAT}, 0.02 \mathrm{~L} \mathrm{ha}^{-1}$ caused senescence in $83 \%$ of the plants, while treatments with $0.10 ; 0.20$ and $0.40 \mathrm{~L} \mathrm{ha}^{-1}$ resulted in $100 \%$ plant senescence (Figure $2 \mathrm{~b}$ ). 
(a)

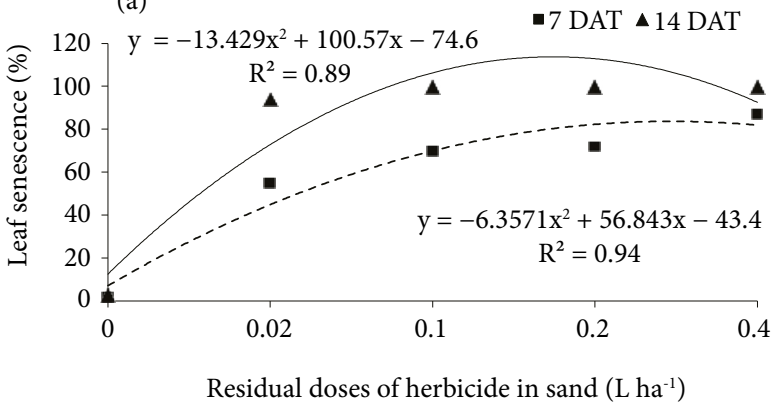

(b)

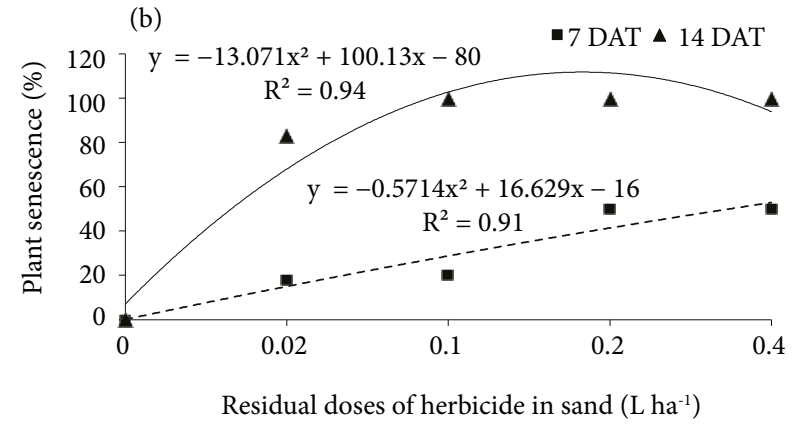

Figure 2. Senescence of leaves (a) and plants (b) in seedlings of Hymenaea stigonocarpa submitted to residual doses of the herbicide 2,4-D + picloram applied in sand substrate.

Plant dry weight, measured 45 days after seedling transplantation, was only assessed in treatments with subdoses between 0 and $0.02 \mathrm{~L} \mathrm{ha}^{-1} 2,4-\mathrm{D}+$ picloram. The remaining treatments killed the plants and they were not considered in this assessment. No significant difference was observed between the treatments (Table 2).

The use of $0.02 \mathrm{~L} \mathrm{ha}^{-1}$ subdoses of herbicide killed plants, which directly affected dry weight (Table 2). Several studies have reported that a decline in this variable is common in most susceptible plants. Hansen \& Grossmann (2000) observed that applying 2,4-D + picloram caused an overproduction of ethylene, triggering abscisic acid (ABA), which results in stomatal closure, thus, limiting carbon assimilation and biomass production. Furthermore, Ashton \& Crafts (1973) report that when seedlings of susceptible species are sprayed with 2,4-D, their normal growth pattern changes rapidly, meristematic cells stop dividing, and elongated cells stop growing.

Table 2. Leaf (LDM), stem (SDM), root (RDM) and total (TDM) dry mass in seedlings of Hymenaea stigonocarpa submitted to residual doses of the herbicide 2,4-D + picloram applied in sand substrate.

\begin{tabular}{ccccc}
\multirow{2}{*}{$\begin{array}{c}\text { Treatments } \\
\left(\mathrm{L} \mathrm{ha}^{-1}\right)\end{array}$} & LDM & SDM & RDM & TDM \\
\cline { 2 - 5 } & \multicolumn{4}{c}{ g plant $^{-1}$} \\
0 & $1,06 \mathrm{~ns}$ & $1.55 \mathrm{~ns}$ & $5.04 \mathrm{~ns}$ & $7.65 \mathrm{~ns}$ \\
0.02 & 1.22 & 1.47 & 4.84 & 7.52 \\
CV & 34.63 & 25.46 & 34.44 & 26.53 \\
\hline
\end{tabular}

Up to 84 days after its use, the residual effect of picloram in agricultural areas causes senescence in successor crops (Stizolobium aterrimum and Canavalia ensiformis) (Mancuso et al., 2011). Additionally, applying $0.25 \mathrm{~L}$ of 2,4-D + picloram results in senescence of soybean plants used as a successor crop (Franceschi et al., 2015). All of these characteristics corroborate the senescence results obtained for Hymenaea stigonocarpa plants (Figure 2).

In an experiment conducted with lettuce (Lactuca sativa L.), tomato (Lycopersicon esculentum Mill.) and cucumber (Cucumis sativus $\mathrm{L}$.), the phytotoxicity of 2,4 $\mathrm{D}+$ picloram rose with higher doses, ranging between 0.02 and 0.04 ha $^{-1}$ (Nascimento \& Yamashita, 2009). Auxin herbicides such as 2,4-D and picloram affect the physiological parameters of the plant, damaging mesophyll cells and causing thylakoid elongation and dilation. The overproduction of Superoxide radical $\left(\mathrm{O}_{2}^{-}\right)$and hydrogen peroxide $\left(\mathrm{H}_{2} \mathrm{O}_{2}^{-}\right)$may also occur in plants treated with these herbicides (Romero-Puertas et al., 2004). This overproduction causes oxidative stress, with concomitant protein degradation and cell death, which leads to symptoms of phototoxicity.

Applying residual doses of 2,4-D + picloram in soil (Red Latosol-experiment III) caused significant decreases in the emergence (Figure 3a) and emergence speed index of seedlings (Figure $3 \mathrm{~b}$ ).
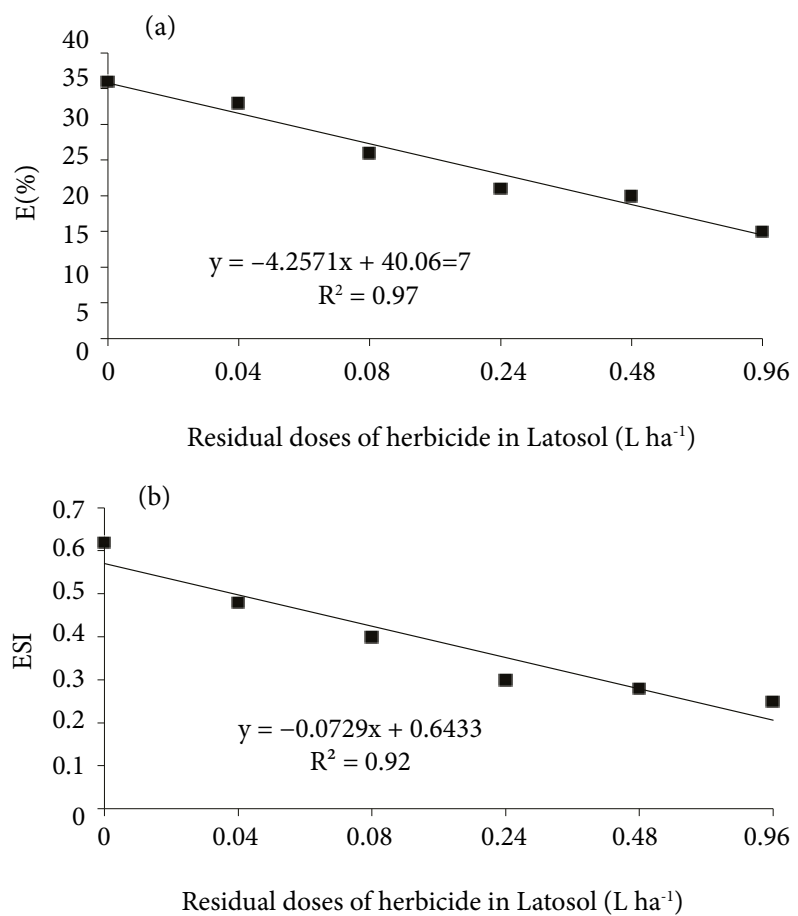

Figure 3. Emergency percentage-E (a) and emergency speed index-ESI (b) in seeds of Hymenaea stigonocarpa sown on contaminated soil with residual doses of the herbicide 2,4-D + picloram applied in Red Latosol. 
The increase in residual doses of 2,4-D + picloram led to a decline of $8,27,41,44$, and $58 \%$ in seedling emergence, applying $0.04 ; 0.08 ; 0.24 ; 0.48$, and $0.96 L h a^{-1}$, respectively, compared to the control (Figure 3a). This reduction was demonstrated by the emergence speed index (ESI) for treatments with 0.24 ; $0.48 ; 0.96 \mathrm{~L} \mathrm{ha}^{-1}$, respectively (Figure 2b).

The smaller effect of 2,4-D + picloram on Hymenaea stigonocarpa seed germination in soil compared to seeds grown in sand, may be related to the clay proportion (Figure 3). Higher adsorption and herbicide persistence generally occur in soils with higher clay proportion as well as low desorption indices, leaching and degradation (Hager \& Nordby, 2004; Vivian et al., 2007). Thus, the clay proportion present in the soil that the planting occurred (approximately 50\%) likely caused a decline in herbicide concentration in the soil solution that entered into contact with the seeds, which did not affect the emergence as significantly as the experiment performed in sand.

\section{CONCLUSIONS}

Applying subdoses of 2,4-D + picloram (0.02; $0.1 ; 0.2$ and $\left.0.4 \mathrm{~L} \mathrm{ha}^{-1}\right)$ in sand inhibits the emergence and initial growth of Hymenaea stigonocarpa seedlings. These doses reduced the SPAD index and increased the senescence.

The herbicide subdoses did not result in complete inhibition when applied in Red Latosol clay soil, but they reduced the emergence and emergence speed index, showing that Hymenaea stigonocarpa may be susceptible to damage, if cultivated in soils with residues of 2,4-D + picloram.

\section{ACKNOWLEDGEMENTS}

The authors are grateful to Centro Universitário de Patos de Minas (Unipam) and the editors' reviews.

\section{SUBMISSION STATUS}

Received: 28 Oct. 2017

Accepted: 4 Feb. 2019

Associate editor: Natália Corniani

D 0000-0001-7342-5171

\section{CORRESPONDENCE TO}

\section{Walquíria Fernanda Teixeira}

Universidade de São Paulo (USP), Campus Luiz de Queiroz, Av. Carlos Botelho, 853, ap. 4, São Dimas, CEP 13416145, Piracicaba, SP, Brasil

e-mail: walquiria_bio@hotmail.com

\section{REFERENCES}

Alvarenga MIN, Gontijo RAN, Alves HMR, Nogueira ND, Nóbrega JCA. Destinação segura das embalagens vazias de agrotóxicos. Informe Agropecuário 2003; 24(220): 7-17.

Ashton FM, Crafts AS. Mode of action of herbicides. New York: John Wiley; 1973.

Barros RE, Tuffi Santos LD, Cruz LR, Faria RM, Costa CA, Felix RC. Physiological response of eucalyptus species grown in soil treated with auxin-mimetic herbicides. Planta Daninha 2014; 32(3): 629-638. 10.1590/S0100-83582014000300019

Bendito BPC, Souza PA, Ferreira RQS, Cândido JB, Souza PB. Espécies do cerrado com potencial para recuperação de áreas degradadas, Gurupi (TO). Revista Agrogeoambiental 2018; 10(2): 99-110. 10.18406/2316-1817v10n220181117

D’Antonino L, Silva AA, Ferreira LR, Cecon PR, Quirino ALS, Freitas LHL. Efeitos de culturas na persistência de herbicidas auxínicos no solo. Planta Daninha 2009; 27(2): 371-378. 10.1590/ S0100-83582009000200021

Durigan G. Bases e diretrizes para a restauração da vegetação de cerrado. In: Kageyama PY, Oliveira RE, Moraes LFO, Engel VE, Gandara FB, editors. Restauração ecológica de sistemas naturais. Botucatu: FEPAP; 2003. p. 187-204.

Empresa Brasileira de Pesquisa Agropecuária - Embrapa. Centro Nacional de Pesquisa de Solos. Sistema brasileiro de classificação de solos. 2nd ed. Rio de Janeiro: Embrapa Solos; 2006. 306 p.

Ferreira DF. Sisvar: sistema de análise de variância. Versão 5.3. Lavras: UFLA; 2010.

Franceschi M, Felito RA, Yamashita OM, Lorenzon J, Carvalho MAC. Lixiviação do herbicida 2,4-D + picloram em Latossolo vermelho amarelo distrófico. Enciclopédia Biosfera 2015; 11(22): 2151-2161.10.18677/Enciclopedia_Biosfera_2015_188

Hager A, Nordby D. Herbicide persistence and how to test for residues in soils. In: Bissonnette S. Ilinois agricultural pest management handbook. Illinois: University of Illinois; 2004. p. 323-326.

Hansen H, Grossmann K. Auxin-induced ethylene triggers abscisic acid biosynthesis and growth inhibition. Plant Physiology 2000; 124(3): 1437-48. 10.1104/pp.124.3.1437

Johnson CM, Stout PR, Broyer TC, Carlton AB. Comparative chlorine requirement of different plant species. Plant and Soil 1957; 8(4): 337-353. 10.1007/BF01666323

Maguire JD. Speed of germination-aid in selection and evaluation for seedling emergence and vigor. Crop Science 1962; 2(1): 176-177. 10.2135/cropsci1962.0011183X000200020033x

Mancuso MAC, Negrisoli E, Perim L. Efeito residual de herbicidas no solo ("Carryover"). Revista Brasileira de Herbicidas 2011; 10(2): 151-164. 10.7824/rbh.v10i2.106

Marschner P. Mineral nutrition of higher plants. 3rd ed. Amsterdam: Elsevier; 2012.

Mulder EG, Boxma R, Van Veen WL. The effect of molybdenum and nitrogen deficiencies on nitrate reduction in plant tissues. Plant Soil 1959; 10(4): 335-355. 10.1007/BF01666209

Nascimento ER, Yamashita OM. Desenvolvimento inicial de olerícolas cultivadas em solos contaminados com resíduos de 
2,4-d + picloram. Semina: Ciências Agrárias 2009; 30(1): 47-54. 10.5433/1679-0359.2009v30n1p47

Peres-Oliveira MA, Bonfim-Silva EM, Silva VM, Vieira ECS. Persistence of 2,4-D and glyphosate in a Cerrado soil, Brazil. African Journal of Agricultural Research 2016; 11(11): 912-919. 10.13140/RG.2.1.4903.8481

Romero-Puertas MC, Rodríguez-Serrano M, Corpas FJ, Gómez M, Del Río A, Sandalio LM. Cadmium-induced subcellular accumulation of $\mathrm{O} 2$ and $\mathrm{H} 2 \mathrm{O} 2$ in pea leaves. Plant Cell and Environment 2004; 27: 1122-1134. 10.1111/j.1365-3040.2004.01217.x
Silva AA, Vivian R, D’Antonino L. Dinâmica de herbicidas no solo. Viçosa: Universidade Federal de Viçosa; 2009.

Tomaz MA. Guia de acompanhamento de aulas de manejo de plantas invasoras. Alegre: Universidade Federal de Espírito Santo; 2011.

Vivian R, Guimarães AA. Queiroz MELR, Silva AA, Reis MRV, Santos JB. Adsorção e dessorção de trifloxysulfuron-sodium e ametryn em solos brasileiros. Planta Daninha 2007; 25(1): 97-109. 10.1590/S0100-83582007000100011 